\title{
Applications submitted and grants awarded to men and women in nationwide biomedical competitive research, in 2006, in Spain
}

\author{
Rosana Peiró-Pérez, Concha Colomer-Revuelta, Margarita Blázquez-Herranz, Fernando Gómez- \\ López
}

Background: According to European reports, women participate in research less than men, especially in positions of responsibility. This kind of analysis has not been carried out in Spain in the field of biomedical research. This study describes participation of men and women as grant applicants in two different calls for research funding, held in Spain in 2006.

Methods: Data collected from grant applicants and from grantees, for two different competitive grant researches areas: human resources and CIBER (Spanish acronym for Biomedical Research Network Centres) have been described by sex.

Results: The human resources call shows that the number of applications submitted by women is higher (67.8\% vs $32.2 \%)$, but the percentage of awards are similar $(20.3 \%$ vs $22.7 \%)$, $\mathrm{OR}=1.15(95 \% \mathrm{Cl}: 0.82$ to 1.62$)$, with no statistical differences, although there are more men in the upper categories (superior technical experts $(O R=1.19 \quad(0.58$ to 2.45)) post-doctoral $(O R=1.36(0.65$ to 2.86$))$ and research personnel $(O R=1.48(0.67$ to 3.25$))$. With the CIBER call (senior researchers) there is a clear difference in the number of applicants (women 19.6\%, men $80.4 \%$ ) but the number of awardees is similar (40.3\% vs $43.1 \%) \mathrm{OR}=0.89(0.65$ to 1.34).

Conclusions: Although there are no statistical differences between women and men, with respect the awards obtained, there is a different pattern to the type of grant application, with fewer women in the more senior call.

C oncern about the scarcity of women conducting research gave rise to the creation in 1988, of a group of female experts who drafted the ETAN Report (European Technology Assessment Network). In it, the existing gender inequalities in the science communities of Western countries were depicted. ${ }^{1}$

According to this report, even though the number of graduating women is high (in Spain it reaches 58\%) this does not translate later into positions of responsibility. This also applies to the under-40 age group. ${ }^{2}$

Helsinki ${ }^{3}$ and ETAN $^{1}$ work groups, under the auspices of the European Union, recommended the analyses of the number of men and women devoted to science in each country and the dissemination of results found. From the study of those data, in Spain, the situation is similar to that of other European countries: women's presence, despite their technical and scientific skills, is lower than that of men in positions of responsibility within the Spanish system of science and technology. ${ }^{4}$

This kind of analysis has not yet been carried out in the field of biomedical research.
This study's objectives are to describe the degree of participation of men and women as applicants for grants and their success rates in obtaining them, at the two calls issued by the Spanish National Health Research Agency in 2006. We also aim to discuss how it could be related to gender inequalities.

\section{METHODOLOGY}

A descriptive study by sex on applications and awarding of financial grants for research support at the different 2006 competition calls made in Spain by the National Health Research Agency (Spanish acronym: ISCIII)

Analysed calls have been: (a) human resources grants (different types of contracts for engaging research personnel); (b) research projects for the "Biomedical Research Networks Centres" (Spanish acronym: CIBER).

Each selected call presents a particular profile. The one for human resources involves contracting professionals with different levels of experience and training (from basic training to greater experience). The CIBER call addresses finance projects proposed by researchers with wide and reputable research experience.

The source of information was from the research agency and the databases are available on their website. ${ }^{5}$

Frequencies of application and awarding, broken down by sex and type of call, were calculated. Also the percentage of grants awarded from those who applied have been used in order to show the rate of success for women and men in each group of calls. Odds ratios and their 95\% confidence intervals for the "risk" of awarding an application according to sex (men vs women) and the p value where also calculated.

\section{RESULTS}

With respect to the call for human resources grants (table 1), results show that the number of women's applications is higher than that of men's, both in overall results (67.8\% vs $32.2 \%)$, and for each one of the types of jobs offered.

Regarding applications description by personnel categories, a similar number of applications by men and women were awarded grants $(\mathrm{OR}=1.15(0.82$ to 1.62$))$, with no statistical differences, although there are more men in the upper categories (superior technical experts OR $=1.19$ (0.58 to 2.45) post-doctoral $\mathrm{OR}=1.36(0.65$ to 2.86$)$ and research personnel $\mathrm{OR}=1.48$ (0.67 to 3.25$)$.

As regards the CIBER call (table 2), there is a difference in the number of applicants (women $19.6 \%$, men $80.4 \%$ )) but not in the number of awardees, $40.3 \%$ of men and $43.1 \%$ of women.

Within specialties, the percentages of applications differed from grants awarded. Whereas most applicants are men, more awardees were women in four of the seven categories, were similar in one category and lower in two categories. The differences are not statistically significant. 
Table 1 Number and percentage of grant applications, and grants awarded to men and women in the call for human resources contracts in 2006

\begin{tabular}{|c|c|c|c|c|c|c|c|c|c|c|}
\hline & \multicolumn{2}{|l|}{ Men } & \multicolumn{2}{|l|}{ Women } & \multirow[b]{2}{*}{ OR $(95 \% \mathrm{Cl})$} & \multirow[b]{2}{*}{ p Values } & \multicolumn{4}{|l|}{ Total } \\
\hline & Applications & $\begin{array}{l}\text { Awarded (\% } \\
\text { men awarded) }\end{array}$ & Applications & $\begin{array}{l}\text { Awarded } \\
\text { (\% women } \\
\text { awarded) }\end{array}$ & & & Applications & $\begin{array}{l}\text { (\% women } \\
\text { applicant) }\end{array}$ & Awarded & $\begin{array}{l}\text { (\% women } \\
\text { awarded) }\end{array}$ \\
\hline $\begin{array}{l}\text { Research } \\
\text { personnel }\end{array}$ & 72 & $14(19.4)$ & 114 & $16(14.0 \%)$ & $1.48(0.67$ to 3.25$)$ & 0.45 & 186 & (61.3) & 30 & (53.3) \\
\hline Post-doctoral & 66 & 15 (22.7) & 118 & $21(17.8 \%)$ & $1.36(0.65$ to 2.86$)$ & 0.46 & 184 & (64.7) & 36 & (58.3) \\
\hline $\begin{array}{l}\text { Superior } \\
\text { technical experts }\end{array}$ & 43 & $20(46.5)$ & 97 & $41(42.3 \%)$ & $1.19(0.58$ to 2.45$)$ & 0.47 & 140 & (69.2) & 61 & (67.2) \\
\hline Pre-doctoral & 101 & $15(14.8)$ & 261 & $42(16.0 \%)$ & $0.91(0.48$ to 1.73$)$ & 0.30 & 362 & (72.9) & 57 & (73.7) \\
\hline Total & 282 & $64(22.7)$ & 590 & $120(20.3 \%)$ & 1.15 (0.82 to 1.62$)$ & 0.38 & 872 & (67.8) & 184 & (65.2) \\
\hline
\end{tabular}

\section{DISCUSSION}

Results show that there exist different patterns between men and women when it comes to applying for grants and also in the type of grants awarded to men and women. Women applied more than men at any specialty level in the call for human resources, and although men proportionally obtained better results in some of them, those differences are not statistically significant. In the CIBER call, women generally apply for fewer projects than men, although the percentage of grants awarded to female applicants is similar to that of male applicants.

The two grant competition calls selected for this study could be representative of the start of a research career and its consolidation. It is young people who, in general terms, apply for the contract offer in the human resources call, whereas mostly expert researchers present projects to the CIBER call.

The different pattern of women applying for the human resources and CIBER calls could have different explanations. One would be that differences are related to cohort effects but as women are now participating more in research, in the future the contribution of women and men should be the same. Another explanation would be that although many women try to enter and to remain in the research field, there are some "gender barriers" and only a highly competitive group of them remains.

These two hypotheses have been tested by reports from the European Commission, ${ }^{13}$ and from the analysis of different stages of the career development. ${ }^{6-9}$ Against the cohort effect it has been shown that the incorporation of women into high positions in the research field is slower than the number of women who obtain university degrees each year.
This study is limited as it only analyses two competition calls in a period of one year, There is a need for further analysis of different calls and trends in time to be conducted, and produce more strongly founded conclusions. Age cohorts should also be analysed to evaluate if changes have occurred towards equal opportunities for men and women in research. Specific studies will equally have to be conducted to know better where difficulties lie for women to gain access and progress in their research career. Some research in Spain shows that there are differences in the distribution of men and women among the research positions at universities but very few of those individuals are aware of the gender barriers..$^{9-11}$

In relation to actions arising from research policies, a strategy for improvement of women's access to all levels of research work should be considered; not only would it be a matter of equal rights but also of improvement in the quality of the research, by increasing the competent human capital. The type of measures might be similar to those established when access to some sectors of research or international competitiveness problems were detected. It is usual for countries to invest in support for research in order to improve their returns from international research funds and, in their domestic sphere, for regions to do the same with domestic funds, all of it intended to correct unjust and avoidable imbalances. Something similar should be implemented with women in science, investing in specific support until they obtain similar positions to men in the research field. We believe that our results are illustrative enough to encourage both continuing research on the issue and establishing mechanisms to support women's careers as researchers.

Table 2 Number and percentage of grants applications and awarded to men and women for the purpose of financing projects in the Biomedical and Health Sciences Research Network Centres (CIBER) in 2006

\begin{tabular}{|c|c|c|c|c|c|c|c|c|}
\hline & \multicolumn{2}{|l|}{ Men } & \multicolumn{2}{|l|}{ Women } & \multicolumn{4}{|l|}{ Total } \\
\hline & Solicited & $\begin{array}{l}\text { Awarded (\% } \\
\text { men awarded) }\end{array}$ & Solicited & $\begin{array}{l}\text { Awarded }(\% \\
\text { women awarded }\end{array}$ & Solicited & $\begin{array}{l}\text { (\% women } \\
\text { solicited) }\end{array}$ & Awarded & $\begin{array}{l}\text { (\% women } \\
\text { Awarded) }\end{array}$ \\
\hline $\begin{array}{l}\text { Bioengineering biomaterials and } \\
\text { nanomedicine }\end{array}$ & 77 & $22(28.5)$ & 10 & $8(80.0)$ & 87 & (11.5) & 30 & $(26.7)$ \\
\hline Epidemiology and public health & 71 & $28(39.4)$ & 18 & $10(55.5)$ & 89 & (20.2) & 38 & (26.3) \\
\hline $\begin{array}{l}\text { Physiopathology of obesity and } \\
\text { nutrition }\end{array}$ & 47 & $16(34.0)$ & 15 & $4(26.6)$ & 62 & $(24.2)$ & 20 & $(20.0)$ \\
\hline Respiratory diseases & 73 & $36(49.3)$ & 12 & $2(16.6)$ & 85 & (14.1) & 38 & (5.3) \\
\hline Hepatic and digestive diseases & 75 & $36(48.0)$ & 21 & $10(47.6)$ & 96 & $(21.9)$ & 46 & (21.3) \\
\hline Neurodegenerative diseases & 54 & $22(40.7)$ & 7 & $4(57.1)$ & 61 & (11.5) & 26 & (15.4) \\
\hline Rare diseases & 79 & $32(40.5)$ & 23 & $12(52.2)$ & 102 & (22.5) & 44 & (27.3) \\
\hline Total & 476 & $192(40.3)$ & 116 & $50(43.1)$ & 592 & (19.6) & 242 & $(20.7)$ \\
\hline OR total $(95 \% \mathrm{Cl})$ & $0.89(0.61$ to 1.34$)$ & & & & & & & \\
\hline$p$ Value & 0.32 & & & & & & & \\
\hline
\end{tabular}




\section{Authors' affiliations}

Rosana Peiró-Pérez, Concha Colomer-Revuelta, Womens Health Observatory, Spanish Ministry of Health and Consumers Affairs, Spain Rosana Peiró-Pérez, Public Health Center in Alzira, Valencian Regional Government and Biomedical Reasearch Network Centre on Epidemiology and Public Health, Spain

Margarita Blázquez-Herranz, Fernando Gómez-López, Nacional Research Agency. Spanish Ministry of Health and Consumers Affairs, Spain

Correspondence to: Rosana Peiró-Pérez, Centro de Salud Pública de Alzira, C/Pau s/n 46600 Alzira, Valencia, Spain; peiro_ros@gra.es

Accepted 30 August 2007

\section{REFERENCES}

1 ETAN Work Group for Women and Science. Policies in the European Union: promoting excellence through mainstreaming gender equality, [Monograph on the internet]. Brussels: Directorate General for Research, Women \& Science.European Commission; 2001 [Accessed 17 January 2007] Available from:http://cordis.europa.eu/improving/women/documents. htm.

2 Hernández Armenteros J (coordinador). La Universidad Española en Cifras. [Monografía en Internet] Madrid: Conferencia de Rectores de las Universidades Españolas, Observatorio Universitario:2004 (Spanish Universities in figures.[Monograph on the internet]. Madrid:Rector's Conference of Spanish Universities. University Observatory. [Accessed 28 Mar 2007] Available from: http://www.crue.org/observatorio.htm.

3 Rees T. The Helsinki Group on Women and Science. National policies on women and science in Europe. [Monograph on the Internet]. Brussels: Directorate General for Research/RTD-C5-Women \&Science. European Commission; 2002.
[Accessed 2007 May 9]. Available from: http://ec.europa.eu/research/sciencesociety/pdf/women_national_policies_full_report.pdf.

4 Informe mujeres investigadoras 2006, [Monografia en Internet].Secretaría General.Subdirección general de recursos humanos. Madrid: Consejo Superior de Investigaciones Científicas; 2006 (Report on Women researcher's 2006, [Monograph on the internet] General Secretary. General Subdirectorate of Human Resources).Madrid:Scientific Research Council. [Accessed 7 May 2007] Available from: http://www.csic.es/wi/mujer_ciencia/archivos_descargar/ informe mujeres_2006.pdf.

5 Ayudas y subvenciones 2006. [Base de datos en Internet]. Madrid: Instituto de Salud Carlos III: 2006. (Grants 2006 [database on the internet] Institute of Health Carlos III. [Accessed 10 Nov 2006] Available from: http://www.isciii.es/isps/ organizacion/evaluacion_fomento/convocatorias/ Fondo_convocatorias_plantillable.jsp.

6 Jagsi R, Guancial EA, Worobey CC, et al. The "gender gap" in authorship of academic medical literature - a 35 -year perspective. N Engl J Med 2006;355:281-7.

7 Nattinger BA. Promoting the career development of women in academia. Med Arch Intern Med 2007;167:323-4.

8 Dickersin K, Fredman L, Flegal KM, et al. Is there a sex bias in choosing editors. Epidemiology journals as an example. JAMA 1998;280:260-4.

9 McManus IC, Sproston KA. Women in hospital medicine in the United Kingdom: glass ceiling, preference, prejudice or cohort effect? J Epidemiol Community Health 2000;54:10-16.

10 Guil-Bozal A, Solano-Parés A, Alvarez-Girón M. La situación de las mujeres en las Universidades Públicas Andaluzas, Consejo Económico y Social de Andalucía. (The women situation in the Andalusian Public Universities. Andalusian Social and Economic Council): Sevilla, 2005.

11 Mujer y ciencia en Aragón. Estado actual y perspectivas, [Monografía en Internet]. Zaragoza: Departamento Ciencia, Tecnología y Universidad 2006 (women and science in Aragón, Actual situation and perspectives. [Monograph on the internet]. Zaragoza: Department of science tecnology and university. [Accessed 8 May 2007] Available from: http://portal.aragob.es/pls/portal30/ docs/FOLDER/CIENCIA/INVESTIGACION/MUJERYCIENCIA_0.PDF. 